Note

\section{Involvement of Hydrophobic Residues in Heat-induced Gelation of Myosin Tail Subfragments from Rabbit Skeletal Muscle}

\author{
Jun-Ichiro MoRITA and Tsutomu YASUI* \\ Experimental Farm, Faculty of Agriculture, \\ Hokkaido University, Sapporo 060, Japan
}

Received August 8, 1990

Myosin solutions form gels when heated under appropriate conditions. ${ }^{1,2)}$ The process of heat-induced gelation of skeletal muscle myosin at high ionic strength was explained as the irreversible aggregation of the globular head segments of myosin molecules and network formation resulting from the unfolding of helical tail segments. ${ }^{3)}$ Proteolysis of myosin with trypsin or chymotrypsin produces tail subfragments such as light meromyosin(LMM) and rods. ${ }^{4,5)}$ The tail portion of myosin heavy chain (MHC) is composed of repetitive $\alpha$-helical sequences that assemble in register with another MHC to form a coiled coil. ${ }^{6,7}$ The repetitive sequence of myosin tail segments included 28-amino acid repeats of seven-residue units with hydrophobic residues at specific positions. This organization provide a hydrophobic surface for the interaction between the two MHC subunits. ${ }^{7}$

Borejdo ${ }^{87}$ has reported that the binding site for a surface hydrophobic probe was located in the head region but not in the LMM region of skeletal myosin molecule in its native state. Samejima et $a .^{9,10)}$ have reported that the aromatic amino acids of myosin were transferred from a hydrophobic environment to a more polar environment during thermal treatment, based on their results of fluorescence and difference spectra experiments. However, the relationship between the surface hydrophobicity and the heat-induced gelation of skeletal muscle myosin is still obscure. In this study we examined the changes of hydrophobicity of myosin tail subfragments from skeletal muscle during the formation of gels on heating. The hydrophobic amino acid residues of the myosin tail subfragments began to be exposed at $35-40^{\circ} \mathrm{C}$, attained the maximum at about $65^{\circ} \mathrm{C}$, and decreased at temperatures higher than $65^{\circ} \mathrm{C}$. These changes in hydrophobicity of myosin tail subfragments on heating seem to correspond well to the heat-induced gel forming process of the myosin subfragments.

$c i s$-Parinaric acid (PA) and 2-p-toluidinylnaphthalene- 6-sulfonic acid potassium salt (TNS) were purchased from Molecular Probe, Inc. and Nakarai Chemicals, respectively. Rabbit skeletal muscle myosin was prepared as described by Perry. ${ }^{11 /}$ LMM and myosin rod were prepared by the method of Margossian and Lowey ${ }^{12)}$ with $\alpha$-chymotrypsin. The rigidity of heat-induced gels was measured by a band-type viscometer as reported by Yasui et al. ${ }^{1)}$ Protein was measured with a spectrophotometer at $280 \mathrm{~nm}$ using $E_{1 \%}$ of 5.4 for myosin, 2.2 for myosin rods, and 3.0 for LMM. $^{12)}$ Circular dichroism spectra were recorded on a JASCO J-500 and helix content was calculated by using $[\theta]_{222}$ as described by Chen et al. ${ }^{13)}$ Fluorescence was measured at $20^{\circ} \mathrm{C}$ with a Hitachi $650-40$ spectrofiuorometer in the ratio mode. The wavelengths of excitation and emission for PA fluorescence were $327 \mathrm{~nm}$ and $420 \mathrm{~nm}$, and those for TNS fluorescence were $333 \mathrm{~nm}$ and $445 \mathrm{~nm}$, respectively. In both cases the excitation and emission slits were $2 \mathrm{~nm}$ and $8 \mathrm{~nm}$. Fluorescence intensities were expressed relative to that of a protein solution incubated at $20^{\circ} \mathrm{C}$ for $10 \mathrm{~min}$.

Figure 1 shows the changes in helix content and surface hydrophobicity of LMM on heating. The helix content of

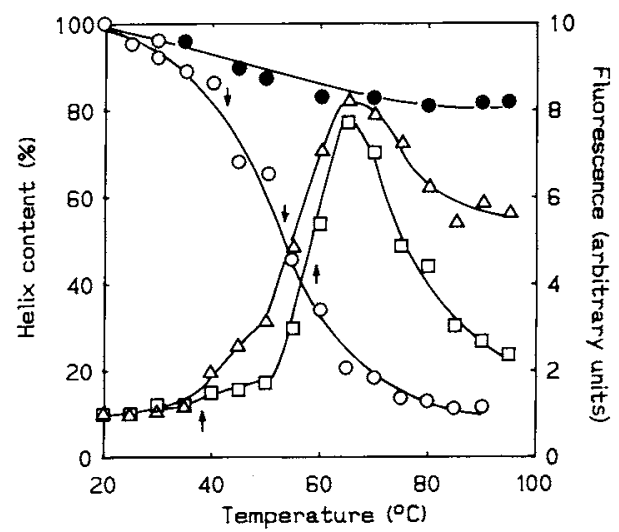

Fig. 1. Effects of Temperature on Helix Content and Fluorescence Intensity of Skeletal LMM.

Helix content: the temperature of a protein solution containing $0.05 \mathrm{mg} / \mathrm{ml} \mathrm{LMM}, 0.6 \mathrm{M} \mathrm{KCl}$, and $20 \mathrm{mM}$ phosphate buffer ( $\mathrm{pH} \mathrm{6.0)}$ was raised and then circular dichroism was measured after $20 \mathrm{~min}(\mathrm{O})$. The reversibility of helix content was examined at $20^{\circ} \mathrm{C}$ after keeping the solution at each temperature for $20 \mathrm{~min}$ followed by cooling to $20^{\circ} \mathrm{C}$ and standing for $10 \mathrm{~min}(\mathrm{O})$. Fluorescence: the solution containing $1 \mu \mathrm{M} \mathrm{LMM}, 0.6 \mathrm{M} \mathrm{KCl}$, and $20 \mathrm{mM}$ phosphate buffer ( $\mathrm{pH}$ 6.0) was held at a constant temperature for $20 \mathrm{~min}$, cooled to and kept at $20^{\circ} \mathrm{C}$ for $10 \mathrm{~min}$, and then fluorescence intensity measurements were began 10 min after adding of $1 \mu \mathrm{M}$ PA $(\Delta)$ or $10 \mu \mathrm{M}$ TNS (口). Arrows indicate transition points obtained by the method of Burke et al. ${ }^{14)}$ 
LMM began to decrease about $30^{\circ} \mathrm{C}$ and attained the minimum at about $70^{\circ} \mathrm{C}$. Two transition points (Tm, shown by arrows, $43^{\circ} \mathrm{C}$ and $53^{\circ} \mathrm{C}$ ) were found, which were almost the same as those of myosin rods. ${ }^{10,14)}$ More than $80 \%$ of the helix content was restored by cooling for only $10 \mathrm{~min}$ at $20^{\circ} \mathrm{C}$ after heating for 20 min even at temperatures higher than $70^{\circ} \mathrm{C}$. Under the same conditions the solution containing a high concentration of LMM have formed a gel, the $\mathrm{Tm}$ of which was single at about $53^{\circ} \mathrm{C}$ (data not shown). The reversibility of the helix content of LMM in this study was comparable to the result for myosin rods reported by Samejima et al. ${ }^{10)}$

It has been reported that 1-anilino-naphthalene-8sulfonate (ANS) ${ }^{15)}$ and $\mathrm{TNS}^{15)}$ were effective fluorescent probes for nonpolar regions of proteins. Fluorescent probes such as PA and ANS have been used to correlate changes in protein surface hydrophobicity with functional properties of muscle foods such as low temperature setting, ${ }^{17}$ emulsifying capacity, ${ }^{18-20}$ and thermal gelation. ${ }^{21,22)}$ The surface hydrophobicity of skeletal myosin tail subfragments was measured by the method of Hayakawa and Nakai ${ }^{23)}$ under conditions similar to those used for measurements of the reversibility of helix content. Heating to $65^{\circ} \mathrm{C}$ progressively increased the hydrophobicity. There was a little difference in profiles between PA and TNS but two Tms from respective profiles were almost the same $\left(38^{\circ} \mathrm{C}\right.$ and $\left.58^{\circ} \mathrm{C}\right)$. Similar results were obtained in experiments using skeletal myosin rods with both probes, except that the fluorescence intensities were slightly higher than those of LMM (data not shown). There are differences in $\mathrm{Tm}$ between helix and fluorescence transitions. The first $\mathrm{Tm}$ of the fluorescence transition $\left(38^{\circ} \mathrm{C}\right)$ is lower than that of the helix transition $\left(43^{\circ} \mathrm{C}\right)$ while the second $\operatorname{Tm}$ of the former $\left(58^{\circ} \mathrm{C}\right)$ is higher than that of the latter $\left(53^{\circ} \mathrm{C}\right)$. It appears likely that the exposure of hydrophobic amino acid residues preceded the helix-coil transition and that the overall helix-coil transition of the myosin tail portion induced the more increase of hydrophobicity. The decrease in hydrophobicity observed at higher temperature suggests involvement of part of the hydrophobic residues in the process leading to the network formation of aggregates. ${ }^{24)}$

The rigidity of heat-induced gels of myosin and myosin tail subfragments become higher by lowering the $\mathrm{pH}$ of medium. The high rigidity at acidic region was explained by the formation of flamentous aggregates of myosin tail segments, which was demonstrated by turbidity, solubility, or electron microscopy. ${ }^{25,26)}$ The surface hydrophobicity of LMM was extensively increased by heating at low $\mathrm{pH}$ region before the increase of rigidity, but it remained low value without heating (Fig. 2). These results suggest that the hydrophobic residues of myosin tail subfragments are exposed to a polar environment by the acidification, that thermal treatment enhances the exposure, and that the increased hydrophobicity promotes the formation of a fine network of filamentous aggregates, which leads to stronger gels at acidic $\mathrm{pH}$ than in neutral or alkaline regions. In

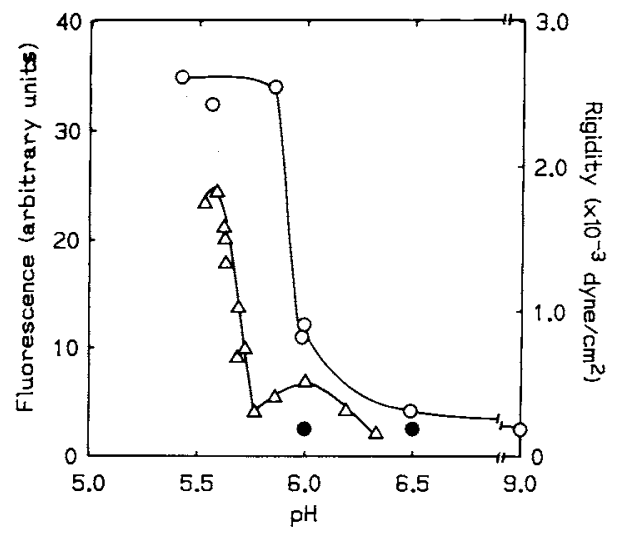

Fig. 2. Effects of $\mathrm{pH}$ on the Fluorescence Intensity of PA with LMM.

A solution consisting of $1 \mu \mathrm{M} \mathrm{LMM}, 0.6 \mathrm{M} \mathrm{KCl}$, and $30 \mathrm{~mm}$ buffer was heated at $65^{\circ} \mathrm{C}$ (O) (or incubated at $20^{\circ} \mathrm{C}$, O) for $20 \mathrm{~min}$, and cooled to and kept at $20^{\circ} \mathrm{C}$ for $10 \mathrm{~min}$. Fluorescence intensity was measured in the presence of $\mathrm{I} \mu \mathrm{M}$ PA. The rigidity $(\triangle)$ of the protein solution $(4.5 \mathrm{mg} / \mathrm{ml}$ LMM) was measured in $0.6 \mathrm{M} \mathrm{KCl}$ and $50 \mathrm{mM}$ buffer after heating at $65^{\circ} \mathrm{C}$ for $25 \mathrm{~min}$. Buffers used were: acetate, $\mathrm{pH}<6$; phosphate, $\mathrm{pH} 6-7.5$; Tris- $\mathrm{HCl}, 8 \leq \mathrm{pH}$.

summary, the results obtained in this study indicate a close relationship between hydrophobicity of skeletal myosin molecule and its heat-induced gelation.

\section{References}

1) T. Yasui, M. Ishioroshi, H. Nakano and K. Samejima, J. Food Sci., 44, 1201 (1979).

2) D. G. Siegel and G. R. Schmidt, J. Food Sci., 44, 1686 (1979).

3) A. Asghar, K. Samejima and T. Yasui, CRC Crit. Rev. Food Sci. Nutr., 22, 27 (1985).

4) S. V. Perry, Biochem. J., 48, 257 (1951).

5) J. Gergely, M. A. Gouvea and D. Karibian, J. Biol. Chem., 212, 165 (1955).

6) D. A. D. Parry, J. Mol. Biol., 153, 459 (1981).

7) A. D. McLachlan and J. Karn, J. Mol. Biol., 164, 605 (1983)

8) J. Borejdo, Biochemistry, 22, 1182 (1983).

9) K. Samejima, K. Takahashi and T. Yasui, Agric. Biol. Chem., 40, 2455 (1976).

10) K. Samejima, M. Ishioroshi and T. Yasui, J. Food Sci., 46, 1412 (1981).

11) S. V. Perry, Methods in Enzym., 2, 582 (1955).

12) S. S. Margossian and S. Lowey, Methods in Enzym., 85, 55 (1982).

13) Y. Chen, J. T. Yang and H. M. Martinez, Biochemistry, 11, 4120 (1972).

14) M. Burke, S. Himmelfarb and W. F. Harrington, Biochemistry, 12, 701 (1973).

15) L. Stryer, J. Mol. Biol., 13, 482 (1965). 
16) W. O. McClure and G. M. Edelman, Biochemistry, 5, 1908 (1966)

17) E. Niwa, K. Sato, R. Suzuki and T. Nakayama, Nippon Suisan Gakkaishi, 47, 817 (1981).

18) L. P. Voutsinas, E. Cheung and S. Nakai, J. Food Sci., 48, 26 (1983).

19) E. Li-Chan, S. Nakai and D. F. Wood, J. Food Sci., 49, 345 (1984).

20) T. Tsutsui, E. Li-Chan and S. Nakai, J. Food Sci., 50, 1268 (1986).

21) J. A. Dudziak, E. A. Foegeding and J. A. Knopp, $J$
Food Sci, 53, 1278 (1988)

22) L. Wicker, T. C. Laniea, J. A. Knopp and D. D. Hamann, J. Agric. Food Chem., 37, 18 (1989).

23) S. Hayakawa and S. Nakai, J, Food Sci., 50, 486 (1985).

24) P. L. Privalov and S. J. Gill, Adv. Protein Chem., 39, 191 (1988).

25) J. Morita, I. Choe, K. Yamamoto, K. Samejima and T. Yasui, Agric. Biol. Chem., 51, 2895 (1987).

26) I. Choe, K. Yamamoto, J. Morita, K. Samejima and T. Yasui, Agric. Biol. Chem, 53, 625 (1989). 